Dhaka Univ. J. Biol. Sci. 20(2): 117-122, 2011 (July)

\title{
SEASONAL PREVALENCE, INTENSITY AND ORGANAL DISTRIBUTION OF HELMINTH PARASITES IN MACROGNATHUS ACULEATUS
}

\author{
Hamida Khanum, Salma Begum and Aleya Begum* \\ Department of Zoology, University of Dhaka, Dhaka-1000, Bangladesh \\ Key words: Macrognathus aculeatus, Helminth, Prevalence, Intensity, Organal distribution, \\ Seasonal variation
}

\begin{abstract}
Examination of 122 individuals of Macrognathus aculeatus (popularly known as Tara Baim), collected monthly, from the river Buriganga during March, 2007 to February, 2008 revealed 77 fishes were infected with various helminth parasites with an infection rate of $63.11 \%$ and intensity of infection of 3.18. A total of 245 parasites were recovered from different organs of the fishes, with the highest number from the intestine. Six species of helminths were detected, of which two were trematodes (Clinostomum piscidum and Rhynchooharynx paradoxa), one species of cestode (Marsipometra parva) and three species of nematodes (Pseudoproleptus vestibules, Cucullanus cirratus and Porrocaecum trichiuri L3 larva). The prevalence and intensity of parasitic infection were a bit higher in female fish than in male. The parasites were much more abundant in rainy season $(75 \%)$ followed by summer $(62.5 \%)$ and winter $(31.81 \%)$. The larger fishes were heavily infected $(71.01 \%)$ than medium $(53.33 \%)$ and smaller $(52.17 \%)$ fishes.
\end{abstract}

\section{Introduction}

The lesser spiny eel, Macrognathus aculeatus, is a tropical fish belonging to the Mastacembelidae family found mostly in Southeast Asian countries, India, Nepal, Pakistan, Sri Lanka, Myanmar and Bangladesh. ${ }^{(1)}$ In Bangladesh it is popularly known as Tara baim and found in rivers, canals, beels and in inundated fields throughout the country.(2,3) The fish is very nutritious and liked by the common people. However, the production of this fish is not in a satisfactory level. The production and growth of this fish are hampered by various ecological and biological factors and also diseases, parasites etc. and of the factors; helminth parasites play a major role.(4) So far, information on the helminth parasites of Macrognathus aculeatus is scanty in Bangladesh, except that of Khanum and Parveen.(5) The present study was aimed at investigating the helminths of Macrognathus aculeatus with emphasis on the organ distribution and seasonal abundance.

\section{Materials and Methods}

A total of 122 host fishes were collected on monthly basis at a regular interval during March, 2007 to February, 2008 from Buriganga river situated near the Dhaka city. After

*Corresponding author. <aleya2000@hotmail.com>. 
collection, the live fishes were kept in polythene bags and brought to the Parasitological Laboratory of Zoology Department, University of Dhaka for detailed investigation. The fishes were examined to determine their parasite community and to study the prevalence of infestation in different length groups. On the basis of the total length of Macrognathus aculeatus (from the tip of the head to the end of the tail fin) the hosts were divided into three length-groups at regular intervals viz., 11 - 17, 17.1 - 23 and 23.1 - 29 $\mathrm{cm}$. The fishes were dissected and removed the digestive tract and urinogenital organs from the body and each organ was put into separate Petri dishes. The stomach, intestine, rectum and pyloric part, gall bladder, liver, kidney, muscles and egg sacs were examined. Trematodes, cestode, nematodes and acanthocephalans were collected from the host and kept in 70\% ethyl alcohol. Then the parasites were removed from alcohol and mounted temporarily in lactophenol to clear the cuticle of the parasites. To make whole mount the trematodes, cestode and nematodes worms were passed through graded of alcohol and stained in borax carmine. They were dehydrated in xylene and mounted in Canada balsam for microscopic study.

\section{Results and Discussion}

Out of 122 fishes (74 males and 48 females), only 77 (45 males and 32 females) were found to be infected with various helminth parasites. A total of 245 parasites were collected from different infested organs. The prevalence of infestation was $63.11 \%$ (both sexes combined). The intensity of infestation was 3.18. Female hosts were more infected than males. The prevalence of infestation of male and female hosts was 60.81 and $66.66 \%$ respectively, (Table 1). In the present study, it was revealed that female hosts were observed to be more infected than males. Similar reports were also observed by Khanum and Parveen ${ }^{(5)}$, Thomas ${ }^{(6)}$, Chandra( ${ }^{(7)}$ and Khanum et al. ${ }^{(8)}$ They concluded that this might be due to lower physiological resistance of female fishes rather than the ecological conditions. Female fishes were generally found to be more susceptible to the parasites than the males as also found by Kennedy and Lie( ${ }^{(9)}$ and Wickins and Macfarlane. ${ }^{(10)}$

The parasites were particularly collected from different parts of the alimentary canal and body cavity. Six species of helminth parasites were recovered, of them two species of trematodes, one species of cestode and three species of nematodes. Among the helminth parasitic groups nematode parasites showed the highest prevalence $(36.05 \%)$ and intensity (3.70) and cestode parasite showed lowest prevalence (4.09\%) and intensity (1.4) (Table 2). The incidence of nematode parasites was higher than the other groups of helminth may be due to the fact that, among the different groups of helminths only nematodes undergo both direct and indirect life cycles. They utilized both soil and aquatic environment. Therefore, it may be possible that fishes get the infection of nematodes directly through ingestion of contaminated soil, algae and other aquatic animals and plants that constitute the major portion of their food. 
The prevalence and intensity of infestation of different species of helminth parasites varied greatly from one another. Six species of helminth parasites were recovered, of them two species of trematodes were Clinostomum piscidum, Southwell et Prashad, 1918;

Table 1. Prevalence and intensity of helminth parasites in male, female and total hosts.

\begin{tabular}{lccccc}
\hline $\begin{array}{l}\text { Host } \\
\text { sex }\end{array}$ & $\begin{array}{c}\text { No. of host } \\
\text { examined }\end{array}$ & $\begin{array}{c}\text { No. of host } \\
\text { infected }\end{array}$ & $\begin{array}{c}\text { Total no. of worm } \\
\text { collected }\end{array}$ & $\begin{array}{c}\text { Prevalence } \\
(\%)\end{array}$ & Intensity \\
\hline Male & 74 & 45 & 148 & 60.81 & 3.28 \\
Female & 48 & 32 & 97 & 66.66 & 3.03 \\
Total & 122 & 77 & 245 & 63.11 & 3.18 \\
\hline
\end{tabular}

Table 2. Prevalence and intensity of different groups of helminth parasites in M. aculeatus.

\begin{tabular}{lccccc}
\hline $\begin{array}{l}\text { Helminth } \\
\text { groups }\end{array}$ & $\begin{array}{c}\text { No. of host } \\
\text { examined }\end{array}$ & $\begin{array}{c}\text { No. of host } \\
\text { infected }\end{array}$ & $\begin{array}{c}\text { Total no. of worm } \\
\text { collected }\end{array}$ & $\begin{array}{c}\text { Prevalence } \\
(\%)\end{array}$ & Intensity \\
\hline Trematoda & 122 & 28 & 75 & 22.95 & 2.67 \\
Cestoda & 122 & 5 & 7 & 4.09 & 1.4 \\
Nematoda & 122 & 44 & 163 & 36.06 & 3.70 \\
\hline
\end{tabular}

and Rhynchooharynx paradoxa, Odhner, 1928; one species of cestode was Marsipometra parva, Cooper, 1917; and three species of nematodes were Pseudoproleptus vestibules, Khera, 1953; Cucullanus cirratus, Moorthy, 1937; and Porrocaecum trichiuri (L3), Ralliet et Henry, 1952. In the present investigation, it was observed that the prevalence and intensity of Cucullanus cirratus were highest (18.85\% and 4.21$)$ and lowest (4.09\% and 1.4$)$ in Marsipometra parva (Table 3). It was also shown that there are some variations in the parasitic fauna compared to Khanum and Parveen(5). They collected five species of helminth parasites from Macrognathus aculeatus, except Rhynchooharynx paradoxa, all the parasites were changed. This variation may be due to the difference in feeding habits and environmental factors of the hosts.

Organal distribution of helminth parasites were found to maximum in intestine (72.25\%), while in the stomach it was $25.71 \%$ and minimum $2.04 \%$ in body cavity (Table 4). According to Marcov(11), fish parasites like other vertebrates, feed either on the digested contents of the host in the alimentary canal or the hosts own tissues. The small intestine seems to be a favourite site for helminth parasites. The abundance of trematode Rhynchooharynx paradoxa and nematodes Cucullanus cirratus and Porrocaecum trichiuri (L3) in the stomach may be explained by the fact that primarily the thick cuticular body covering of the parasites are well adapted to their hosts and secondly they possess a complete or partially complete alimentary canal, so they can take in and digest the undigested food materials from the stomach of the host. The abundance of cestode 
parasite Marsipometra parva in the intestine may be related to their feeding behaviour as they are completely devoid of digestive system. Hence, they absorb the simplest form of nutrients through the cuticle.

Table 3. Prevalence and infestation of helminth parasites in M. aculeatus.

\begin{tabular}{lccccc}
\hline $\begin{array}{l}\text { Name of } \\
\text { parasisites }\end{array}$ & $\begin{array}{c}\text { No. of host } \\
\text { examined }\end{array}$ & $\begin{array}{c}\text { No. of host } \\
\text { infected }\end{array}$ & $\begin{array}{c}\text { Total no. of } \\
\text { worm collected }\end{array}$ & $\begin{array}{c}\text { Prevalence } \\
(\%)\end{array}$ & Intensity \\
\hline $\begin{array}{l}\text { Trematoda } \\
\text { Clinostomum piscidum }\end{array}$ & 122 & 10 & 25 & 8.19 & 2.5 \\
$\begin{array}{l}\text { Rhynchooharynx paradoxa } \\
\text { Cestoda }\end{array}$ & 122 & 18 & 50 & 14.75 & 2.77 \\
$\begin{array}{l}\text { Marsipometra parva } \\
\text { Nematoda }\end{array}$ & 122 & 05 & 07 & 4.09 & 1.4 \\
$\begin{array}{l}\text { Pseudoproleptus vestibules } \\
\text { Cucullanus cirratus }\end{array}$ & 122 & 12 & 43 & 9.83 & 3.58 \\
Porrocaecum trichiuri (L3) & 122 & 23 & 97 & 18.85 & 4.21 \\
& 122 & 09 & 23 & 7.37 & 02 \\
\hline
\end{tabular}

Table 4. Organal distribution of helminth parasites.

\begin{tabular}{|c|c|c|c|c|c|c|}
\hline $\begin{array}{l}\text { Organs } \\
(\%)\end{array}$ & $\begin{array}{c}\text { Clinostomum } \\
\text { piscidum } \\
(\%)\end{array}$ & $\begin{array}{c}\text { Rhynchooharynx } \\
\text { paradoxa } \\
(\%)\end{array}$ & $\begin{array}{c}\text { Marsipometra } \\
\text { parva } \\
(\%)\end{array}$ & $\begin{array}{c}\text { Pseudoproleptus } \\
\text { vestibules } \\
(\%)\end{array}$ & $\begin{array}{l}\text { Cucullanus } \\
\text { cirratus } \\
(\%)\end{array}$ & $\begin{array}{c}\text { Porrocaecum } \\
\text { trichiuri (L3) } \\
(\%)\end{array}$ \\
\hline Body cavity & $\begin{array}{c}5 \\
(2.04)\end{array}$ & - & - & - & - & - \\
\hline Stomach & - & $\begin{array}{c}38 \\
(15.51)\end{array}$ & - & - & $\begin{array}{c}20 \\
(8.16)\end{array}$ & $\begin{array}{c}5 \\
(2.04)\end{array}$ \\
\hline Intestine & $\begin{array}{c}20 \\
(8.16)\end{array}$ & $\begin{array}{c}12 \\
(4.90)\end{array}$ & $\begin{array}{c}7 \\
(2.86)\end{array}$ & $\begin{array}{c}43 \\
(17.55)\end{array}$ & $\begin{array}{c}77 \\
(31.43)\end{array}$ & $\begin{array}{c}18 \\
(7.35)\end{array}$ \\
\hline
\end{tabular}

In the present investigation, maximum infestation was observed in rainy season $(75 \%)$ and minimum in winter season $(31.81 \%)$. Seasonal fluctuation of six species of helminth parasites showed a remarkable variation. In summer Cucullanus cirratus showed highest (32.5\%) prevalence but Clinostomum piscidum showed highest (9.0) intensity (Table 5). In rainy seasons the highest $(21.66 \%)$ prevalence was observed in Rhynchooharynx paradoxa and lowest (5.0) in Marsipometra parva. In winter the infestation rate is very low. Highest (13.63) prevalence occurred in Clinostomum piscidum and lowest (0.0) in Marsipometra parva (Table 6). LaRue ${ }^{(12)}$ reported that there are numerous complex factors that influence the parasitic infestation reached peak during the rainy season. This may be over rainfall, flood, domestic sewage, various kinds of pollutants, less immunity of hosts and presence of huge number of sprouting insects. Lower rate of infestation in winter season may be due to the lack of feeding tendency of the host. Niyogi et al.(13) suggested that this was due to a temperature dependant rejection response. 
Table 5. Overall seasonal variations of helminth parasites in M. aculeatus.

\begin{tabular}{lccccc}
\hline Seasons & $\begin{array}{c}\text { No. of host } \\
\text { examined }\end{array}$ & $\begin{array}{c}\text { No. of host } \\
\text { infected }\end{array}$ & \multicolumn{2}{c}{$\begin{array}{c}\text { Total no. of } \\
\text { worm collected }\end{array}$} & $\begin{array}{c}\text { Prevalence } \\
(\%)\end{array}$ \\
\hline Summer (March - June) & 40 & 25 & 91 & 62.5 & 3.64 \\
Rainy (July - October) & 60 & 45 & 132 & 75 & 2.93 \\
Winter (November - February) & 22 & 07 & 22 & 31.81 & 3.14 \\
\hline
\end{tabular}

Table 6. Seasonal variations of different parasites in M. aculeatus.

\begin{tabular}{|c|c|c|c|c|c|}
\hline \multirow{2}{*}{$\begin{array}{l}\text { Name of } \\
\text { parasites }\end{array}$} & \multicolumn{5}{|c|}{ Summer (March - June) } \\
\hline & $\begin{array}{c}\text { No. of host } \\
\text { examined }\end{array}$ & $\begin{array}{c}\text { No. of host } \\
\text { infected }\end{array}$ & $\begin{array}{l}\text { No. of worm } \\
\text { collected }\end{array}$ & $\begin{array}{c}\text { Prevalence } \\
(\%)\end{array}$ & Intensity \\
\hline Clinostomum piscidum & 40 & 01 & 09 & 2.5 & 9.0 \\
\hline Rhynchooharynx aradoxa & 40 & 04 & 11 & 10.0 & 2.75 \\
\hline Marsipometra parva & 40 & 02 & 03 & 5.0 & 1.5 \\
\hline Pseudoproleptus estibules & 40 & 03 & 23 & 10.0 & 5.75 \\
\hline Cucullanus cirratus & 40 & 13 & 39 & 32.5 & 3.0 \\
\hline \multirow[t]{2}{*}{ Porrocaecum trichiuri (L3) } & 40 & 01 & 07 & 2.5 & 7.0 \\
\hline & \multicolumn{5}{|c|}{ Rainy (July - October) } \\
\hline Clinostomum piscidum & 60 & 06 & 15 & 10.0 & 2.5 \\
\hline Rhynchooharynx paradoxa & 60 & 13 & 36 & 21.66 & 2.76 \\
\hline Marsipometra parva & 60 & 03 & 04 & 5.0 & 1.33 \\
\hline Pseudoproleptus vestibules & 60 & 07 & 17 & 11.66 & 2.42 \\
\hline Cucullanus cirratus & 60 & 09 & 50 & 15.0 & 5.55 \\
\hline \multirow[t]{2}{*}{ Porrocaecum trichiuri (L3) } & 60 & 07 & 10 & 11.66 & 1.42 \\
\hline & \multicolumn{5}{|c|}{ Winter (November - February) } \\
\hline Clinostomum piscidum & 22 & 03 & 01 & 13.63 & 0.33 \\
\hline Rhynchooharynx paradoxa & 22 & 01 & 03 & 4.54 & 3.0 \\
\hline Marsipometra parva & 22 & 00 & 00 & 00 & 00 \\
\hline Pseudoproleptus vestibules & 22 & 01 & 03 & 4.54 & 3.0 \\
\hline Cucullanus cirratus & 22 & 01 & 08 & 4.54 & 8.0 \\
\hline Porrocaecum trichiuri (L3) & 22 & 01 & 06 & 4.54 & 6.0 \\
\hline
\end{tabular}

Prevalence and intensity varied in relation to the host's body length. The individuals of the small length group $(11-17 \mathrm{~cm}$ ) had less prevalence $(52.17 \%)$ than the large length group (23.1 - $29 \mathrm{~cm})$. The intensity was also highest (3.33) in the large length group and lower in small length group (Table 7). Bashirullah(14) reported that the degree of parasitism was obviously related to the food habit and age of the fishes. 
Table 7. Prevalence and intensity of helminth infestation in different length groups.

\begin{tabular}{lccccc}
\hline $\begin{array}{l}\text { Length } \\
\text { groups }(\mathrm{cm})\end{array}$ & $\begin{array}{c}\text { No. of host } \\
\text { examined }\end{array}$ & $\begin{array}{c}\text { No. of host } \\
\text { infected }\end{array}$ & $\begin{array}{c}\text { Total no. of } \\
\text { worm collected }\end{array}$ & $\begin{array}{c}\text { Prevalence } \\
(\%)\end{array}$ & Intensity \\
\hline $11-17$ & 23 & 12 & 37 & 52.17 & 3.08 \\
$17.1-23$ & 30 & 16 & 50 & 53.33 & 3.12 \\
$23.1-29$ & 69 & 49 & 158 & 71.01 & 3.33 \\
\hline
\end{tabular}

\section{References}

1. Jayaram KC 1981. The fresh water fishes of India, Pakistan, Bangladesh, Burma and Sri Lanka. A handbook, Zoological Survey of India, Calcutta. pp. 386.

2. Shafi M and MAA Quddus 1982. Bangladesher Matshya Sampad. (Fisheries of Bangladesh, in Bengali) Bangla Academy, Dhaka. 297-304.

3. Bhuiyan AL 1964. Fishes of Dacca. Asiatic Soc. Pakistan, Publ. No. 13, Dacca. pp. 118-119.

4. Dogiel VA 1961. Ecology of parasites of freshwater fishes. In: Parasitology of fish (VA Dogiel, GK Petrushevski and Yu 1 Polynski, eds). London.Oliver and Boyd. 120-146.

5. Khanum H and S Parveen 1997. Organal distribution and seasonal prevalence of endoparasites in Macrognathus aculeatus Smith and Macrognathus armatus Day. Bangladesh J. Zool. 25(1): 15-21.

6. Thomas JD 1964. A comparison between the helminth burdens of male and female brown trout, Salmo trutta L., from a natural population in the river Teify. West Wales. Parasitology 4: 263-272.

7. Chandra KJ 1985. Records of some Trypanorhych pleurocercoids in teleosts of Andhra coast. Indian. J. Parasitol. 9: 35-137.

8. Khanum H, N Begum and A Begum 2008. Infestation of helminth parasites in the Panna micrdon (Bleeker, 1849). Dhaka Univ. J. Biol. Sci. 17(1): 51-57.

9. Kennedy CR and SF Lie 1974. The distribution and pathogenecity of larvae of Eustrongyllids (Nematode) in brown trout, Salmo trutta L. in Feraworthy Reservoir. Devon J. Fish. Biol. 8: 293-302.

10. Wickins JF and IS Macfarlane 1971. Some differences of parasitic fauna of three samples of plaice (Pleuronectes platessa L.) from the southern North Sea. J. Fish. Biol. 5: 9-19.

11. Markov GS 1946. Modes of feeding of parasites Priroda, XII. (Cited form Dogiel, VW 1961). General parasitology, Leningrad Univ. Press (English translation, Z. Kabata) Oliver and Boyd, Edinburg. pp. 516.

12. LaRue GR 1951. Host-parasite relations among the digenetic trematodes. J. Parasitol. 37: 333-342.

13. Niyogi A, AK Gupta and SM Agrawal 1982. Population dynamics of caryophyllids parasitizing Clarias batrachus at Raipur. Geobios New Reports. 1: 81-93.

14. Bashirullah AKM 1973. A brief survey of the helminth fauna of certain marine and freshwater fishes of Bangladesh. Bangladesh J. Zool. 1 : 63-81. 